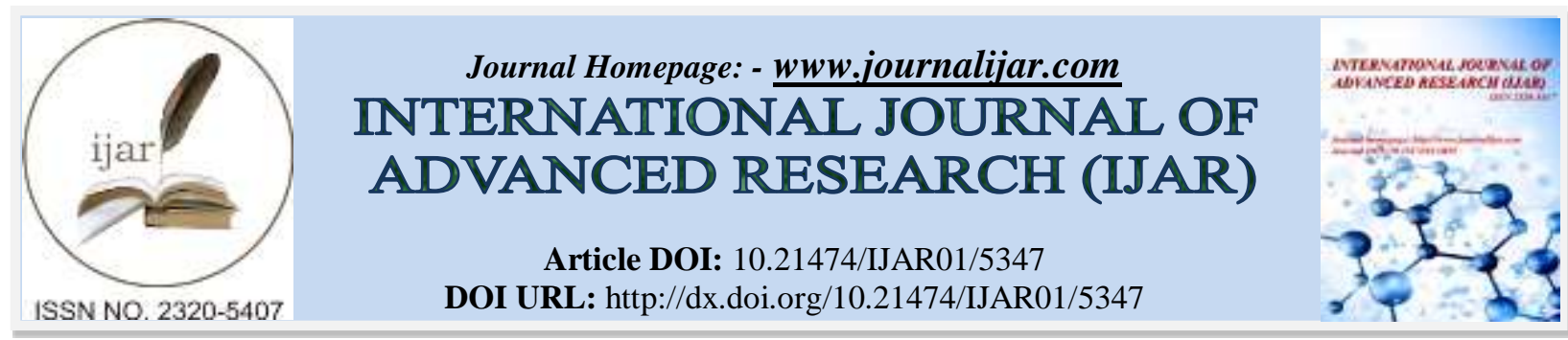

RESEARCH ARTICLE

\title{
FACTORS AFFECTING THE SATISFACTION OF THIRD PARTY LOGISTICS (3PL) CUSTOMERS IN THE APPAREL SECTOR IN SRI LANKA.
}

\section{R. T. A. C. Seneviratne and Wasantha Premarathne.}

Department of Management and Finance, General Sir John Kotelawala Defence University, Ratmalana, Sri Lanka.

\section{Manuscript Info}

Manuscript History

Received: 07 July 2017

Final Accepted: 09 August 2017

Published: September 2017

Key words:-

Third Party Logistics, Outsourcing, Customer Satisfaction, Apparel Industry, Logistics Management, 3PL, Sri Lanka.

\begin{abstract}
As an emerging industry, logistics plays a significant role by providing a helping hand for firms in achieving competitive edge over rivals. Maximizing profits through integrated partnerships is one of the primary objectives of both 3PL providers and their customers when dealing with outsourcing logistics activities. A rapid increase is visible in the number of companies that outsource their logistics activities to 3PL providers. Apparel firms in Sri Lanka have the highest interest in outsourcing logistics activities compared to other industries. However, lack of proper identification and fulfilment of customer requirements, which has ultimately resulted a negative perception in the minds of customers towards their 3PL providers, is a burning issue in this industry. The present study addresses this issue by identifying the factors affecting the satisfaction of 3PL customers in the apparel industry in Sri Lanka. Primary data were collected using a semistructured questionnaire from a random sample of 56 apparel firms. Trust, flexibility, effective communication, openness \& transparency, effective partnering \& collaboration, financial considerations, condition fulfilment, and customer relationships, were considered as the factors influencing 3PL customer satisfaction in apparel sector in Sri Lanka. 3PL customer satisfaction was viewed on two dimensions, namely, switching behaviour and customer loyalty. It revealed that all selected independent variables have positive significant relationship with customer satisfaction, while flexibility of the 3PL provider was the most significant factor that influences customer satisfaction.
\end{abstract}

Copy Right, IJAR, 2017, All rights reserved.

\section{Background:-}

Logistics has become one of the fastest growing industries in every economy. Due to its significant role in achieving competitive advantages, outsourcing logistics activities to a third party is an emerging trend in the modern world. Vaidyanathan (2005) identified a rapid increase in the number of companies that outsource their logistics activities to Third Party Logistics (3PL) providers, to concentrate on their core competencies. Organizations mostly outsource their logistics activities to move ahead with low cost structures. Rahman (2011) identified that cost reduction, reduction in capital investment, enhanced flexibility, access to new market, access to new technology, and focus on core activities, as motivational factors for outsourcing. Further, Premarathne (2012) highlighted that outsourcing of logistics activities reduces excess stock, cost of production, lead-time, resource shortages, overhead costs, and increases production flexibility and quality that leads to better concentration on the core business. Third Party 
Logistics companies provide many services including shipment consolidation, order fulfilment, warehouse management, fleet management, reverse logistics, rate negotiation, carrier selection, logistics information systems, inventory management, product assembly, and order processing.

In the past, the importance of logistics management was not highly recognized by the business sector in Sri Lanka. However, Sri Lanka is now heading towards development in this field and attempts to achieve competitive edge in the market through outsourcing their logistics activities. Hettiarachchi \& Ranwala (2015) highlighted that cost reduction is the key catalyst of outsourcing logistics activities in Sri Lanka. Further they identified that apparel industry in the country has the highest interest in outsourcing logistics activities and warehousing is the most common 3PL service demanded by customers. However, according to Perera (2011), Sri Lanka yet has a long way to proceed in the logistics field.

Apparel industry in Sri Lanka plays a major role in the economy, as it has made Sri Lanka as a world class apparel manufacturer, supplying to global super brands for over three decades. Dheerasinghe (2009) mentions that garment industry in Sri Lanka acts as one of the largest net foreign exchange earner since 1992. Apparel sector in Sri Lanka is renowned for its excellence in speedy delivery and reliability while assuring quality and innovation at global standards. Further, the apparel sector follows ethical industrial practices in labour management, thus known to the world as a producer of 'garments without guilt'. However, Sri Lankan apparel industry is categorized as a low margin market due to its labour-intensive nature. Further, the availability of imported textile and textile articles at a very low price has adversely affected the domestic apparel sector. This has been one main reason for the apparel industry to experience a contraction in the growth rate up to 1.4 percent during 2015, compared to 3.4 percent reported in 2014. On the other hand, Export Development Board (2016) has identified apparel industry as 'a one with conscience and care by protecting workers' rights, creating opportunities for education and personal growth, and helping to alleviate poverty in communities with the aim to create a more equitable society.' The industry provides direct and indirect employment opportunities to over 300,000 and 600,000 respectively, which include a substantial number of women in Sri Lanka and the total value of exports in the apparel sector was US \$ 4,739 million in the year 2014 (Export Development Board, 2016). Sri Lanka has around 300 to 350 apparel manufacturers and exporters, and most export-oriented clothing factories are SMEs and scattered across the country (Export Development Board, 2016).

Customer satisfaction is a key factor for any organization as it paves the path for profitability through customer retention, and Customer satisfaction is the necessary foundation for an organization to retain existing customers (Guo, Xiao \& Tang, 2009). High level of customer satisfaction deceases the intention to switch (Bowen \& Chen, 2001).

Although many researches explore customer satisfaction determinants in different industries, very few research have been conducted locally and globally to identify significant factors affecting 3PL customers' satisfaction in the logistics market. The outcomes of this study assist 3PL providers to distinguish significant factors that affect their customer satisfaction. Further outcomes help 3PL providers in minimizing customer switching behaviour and switching costs, as they have a clear idea about the expectations of customers that should be fulfilled when delivering 3PL services. Outsourcing logistics activities create a platform for 3PL providers and their customers to have a flexible, reliable, and an effective long lasting relationship, which eventually results in better financial performance of both parties. Therefore, the main objective of this paper is to study the factors that influence 3PL customers' satisfaction in the apparel sector in Sri Lanka.

\section{Literature Review:-}

Satisfaction is a person's feeling of pleasure or disappointment that results from comparing a product's perceived performance or outcome with their expectations (Kotler, 2011). Fornell (1992) defined customer satisfaction as the customer's response to the evaluation of the perceived discrepancy between prior expectations and the actual performance of the product or service perceived after its consumption; hence considering satisfaction as an overall post-purchase evaluation by the consumer.

In 3PL industry, customer is a firm. Therefore, customer satisfaction in the B2B context is often defined as ' $\mathrm{a}$ positive affective state resulting from the appraisal of all aspects of a firm's working relationship with another firm' (Geyskens et al., 1999). Two concepts of customer satisfaction are, transaction specific satisfaction and cumulative satisfaction (Bolton \& Drew, 1991; Shankar et al., 2003). Transaction specific is also known as service encounter 
that occurs related to a specific transaction and provides a specific diagnostic information about a particular product or service encounter, whereas in cumulative satisfaction, it is the overall satisfaction that accumulates across a series of transactions or encounters. This study focuses on cumulative satisfaction as it is a more fundamental indicator of the firm's past, current, and future performance.

Consumer switching is the migration of consumers from one service to another (Ranganathan, Seo \& Babad, 2006). Sathish et al. (2011) defined customer switching as an act of being loyal to one service category, but switch from one service provider to another, due to dissatisfaction or any other related problem. Wagner \& Friedl (2007) claimed that partial switching allows customers to have relationships with existing suppliers while seeking new relationships with potential suppliers.

Jacoby \& Kyner (1973) described loyalty as the biased, behavioural response, expressed over time, by some decision-making unit, with respect to one or more alternative brands out of a set of such brands, and is a function of psychological processes. Zeithaml, Berry \& Parasuraman (1996) defined loyalty as an intention to perform a diverse set of behaviours that signal a motivation to maintain a relationship with the focal firm, including engaging in positive word-of-mouth and repeat purchasing.

Customer loyalty is the commitment to buy or purchase a product regularly in future from an organization (Oliver, 1999). Customer loyalty is conceptually similar to commitment (Assael, 1987) and it is mainly categorized as shortterm and long-term loyalty (Jones \& Sasser, 1995).

Service quality is essential to a service company as it can directly have an impact on customer satisfaction (Parasuraman, Zeithaml \& Berry, 1985). Service quality and customer satisfaction are related concepts, occasionally understood to be synonymous, especially by practitioners, but theoretical and empirical research mostly support the view that they are two distinct concepts and quality performance leads to customer satisfaction (Olsen, 2002). It is evident that when the customer is satisfied due to better service quality, it leads to the enhancement of supplier customer relationship. A customer's evaluation of service quality and the resulting level of satisfaction are perceived to affect the bottom line measures of business success (Iacobucci, Grayson \& Ostrom, 1994).

Perception of price fairness and price-quality are considered as the key factors in determination of consumer retention or switching from organization (Gwin \& Lindgren, 1986). Flexibility in logistics is a possibility to a company to quickly and effectively respond to the changing needs of the customer (Autry, Zacharia \& Lamb, 2008; Juga, Juntunen \& Grant, 2010). Kouser et al. (2012) identified that the main reason for customers to switch is the core service failure, which include three sub categories, namely, mistakes, billing errors, and service catastrophes.

Another important reason for customers to switch from one service provider to another is highlighted as service encounter. It refers to personal interaction between the customer and the employees of service providers, which include some aspects of employees' behaviour and their attitudes, comprising uncaring, impoliteness, unresponsiveness, and unknowledgeable qualities. Service recovery is defined as the response to poor service quality (Gro" nroos, 1988). When distinguishing the relationship between service recovery and customer satisfaction, it is identified that effective service recovery leads to higher satisfaction in contrast to service that had been poorly performed on the first time (Etzel, 1981).

Trust is defined as the willingness of a party to the actions of another party, based on the expectation that the other will perform an action important to the trustee, irrespective of the ability to monitor or control that other party (Mayer, Davis \& Schroorman, 1995), and trust has a significant influence on customer satisfaction (Kim, Ferrin \& Rao, 2009). Accordingly, trust helps people to resolve uncertainty regarding the motives, intentions, and prospective actions of others, on whom they depend (Kramer, 1999). Since trust reduces monitoring and legal contract costs, it also allows people to save money and reduce effort (Fortin, Dholakia \& Dholakia, 2002). McKnight \& Chervany (2002) highlighted the characteristics of trust as the willing and ability to act in the customer's best interest, be honest in transactions, and to be both capable of and predictable in delivering as promised. Also, Mayer, Davis \& Schroorman (1995) suggested that a trustee who possesses these traits is suitable as an exchange partner because it is perceived by the client that this trustee will behave skillfully, ethically, kindly, and consistently, in the exchange.

Information sharing is the expectation that the parties will freely and actively provide useful information to each other (Heide \& John, 1992). Hettiarachchi \& Ranwala (2015) claimed that information sharing and good 
communication between the two parties are essential to be excessively mindful of each other and to avoid misunderstandings between the two parties, which finally results in a good inter-firm relationship. It further improves the transparency of decisions related to business matters and builds confidence among partners. Tian, Lai \& Daniel (2008) identified that information sharing is one of the critical factors that builds trust between 3PL provider and its customer for a long-term sustainable relationship.

Sheikh \& Rana (2012) pointed out that third party logistics providers are immensely helpful to enhance customer satisfaction as they support to integrate different processes of supply chain, using advanced tools in Information Technology. As highlighted by Srinivasan, Kekre \& Mukhopadhyay (1994), to increase the shipment performance of suppliers and decrease uncertainty, sharing of information between the supply chain members should be significantly enhanced and improved using Electronic Data Interchange (EDI) technology in the supply chain system. Even Lewis \& Talalayevsky (2000) identified that transaction cost between the supply chain partners can be decreased and some complications can be handled using advanced information technology tools and engage in significant improvements in Information Technology.

\section{Methodology:-}

As per the conceptual framework in Figure 1, customer satisfaction was measured in two dimensions, namely switching behaviour and customer loyalty. The independent variables of the study are openness and transparency, flexibility, trust, effective partnering and collaboration, effective communication, financial considerations, condition fulfilment, and customer relationships. Variables in the study were identified through literature and from the authors' knowledge.

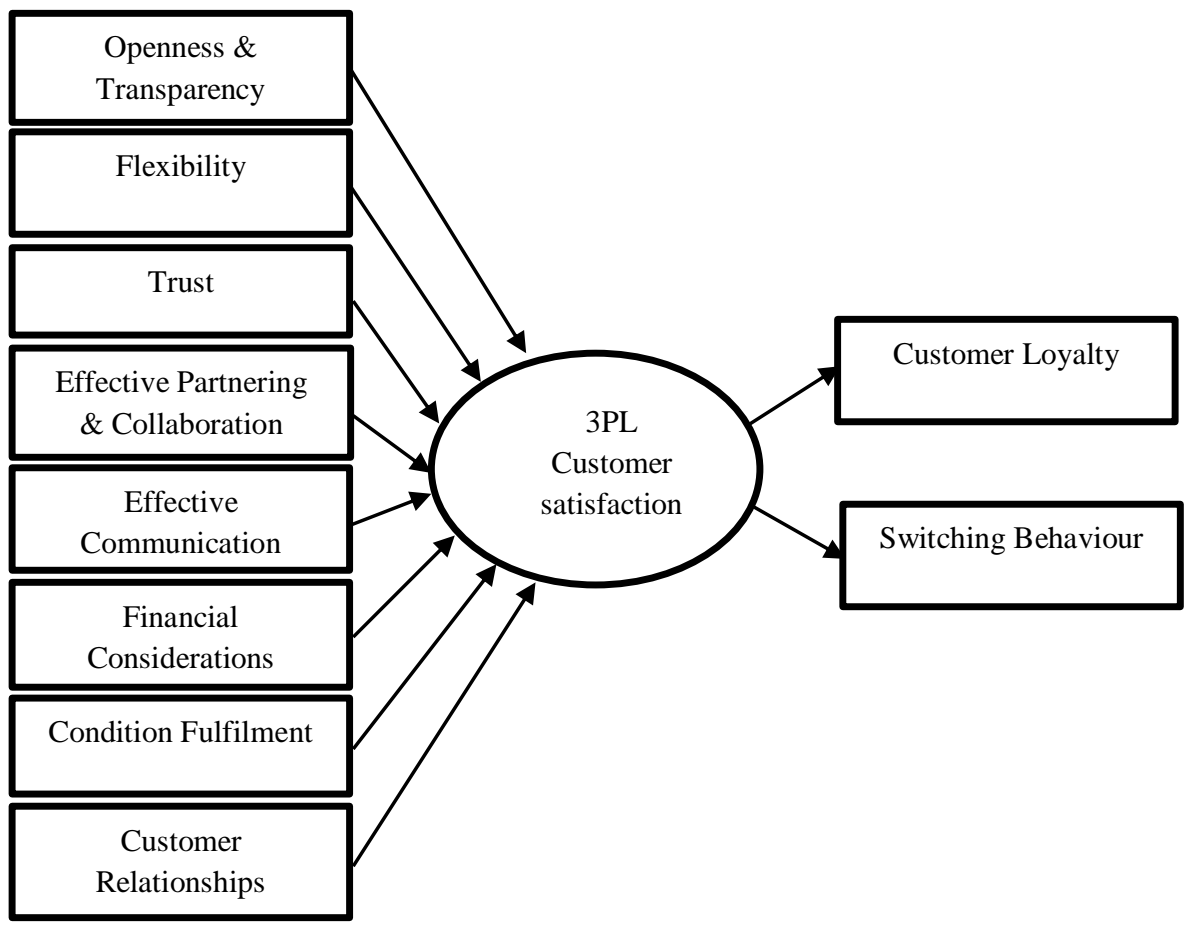

Source: Developed by the authors (2016)

Figure 1:- Conceptual framework of the study

Based on the conceptual framework in Figure 1, the following function can be derived:

CUST $=f(O P T R, F L E X, T R U S, E P C O$, ECOM, FICO, COFU, CURE)

Where, CUST = Customer Satisfaction

OPTR = Openness and Transparency

FLEX $=$ Flexibility

TRUS $=$ Trust

$E P C O=$ Effective Partnering and Collaboration

$E C O M=$ Effective Communication 


$\begin{array}{lll}\text { FICO } & = & \text { Financial Considerations } \\ C O F U & = & \text { Condition Fulfilment } \\ C U R E & = & \text { Customer Relationship }\end{array}$

A five-point Likert scale collected the respondents' opinion, where 1 represents 'strongly disagree' and 5 represents 'strongly agree'.

Apparel industry in Sri Lanka is managed by different regulatory bodies including Ministry of Industry \& Commerce, and Sri Lanka Apparel Exporters' Association. This has caused difficulties in obtaining the sampling frame. For the study, the apparel manufacturers and exporters registered under Sri Lanka Apparel Exporters' Association, which is a member of Joint Apparel Association Forum (JAAF), is considered as the population. Out of 66 members in the population, a sample of 56 members were extracted through simple random sampling technique using 95 percent confidence level and five percent level of confidence interval. The sample mainly consists of largescale apparel firms and few number of medium-scale firms. The sample adequacy was tested using KMO test.

A pilot study was conducted using a sample of ten expertise, each representing major apparel firms in Sri Lanka. The reliability was tested using Cronbach alpha values and through Test-Retest reliability test. The content validity, criterion-related validity, and construct validity, were tested under the test validity. To identify the dimensions of customer satisfaction, a factor analysis was performed, and to observe the impact of independent variables on 3PL customer satisfaction, a regression analysis was conducted using AMOS. The model fit was tested using CMIN/DF, GFI, RMSEA, NFI, and CFI values.

\section{Analysis:-}

The firm establishment period of the sample is dispersed over a range of 10 years to 58 years. The number of employees in the apparel firms of the sample is between 700 and 50,000 and the average number of employees is 13,660. Although there are several 3PL services demanded by the apparel firms, only 8 main activities (warehouse operation, shipment consolidation, transportation, freight forwarding, custom clearance, cross docking, packaging \& labelling, and inventory management) were focused in the study. Out of these functions, warehouse operation has the highest frequency among the 3PL services purchased by apparel firms. Freight forwarding has the second highest frequency, followed by the frequency of transportation. Figure 2 represents 3PL services obtained by apparel firms and their percentages.

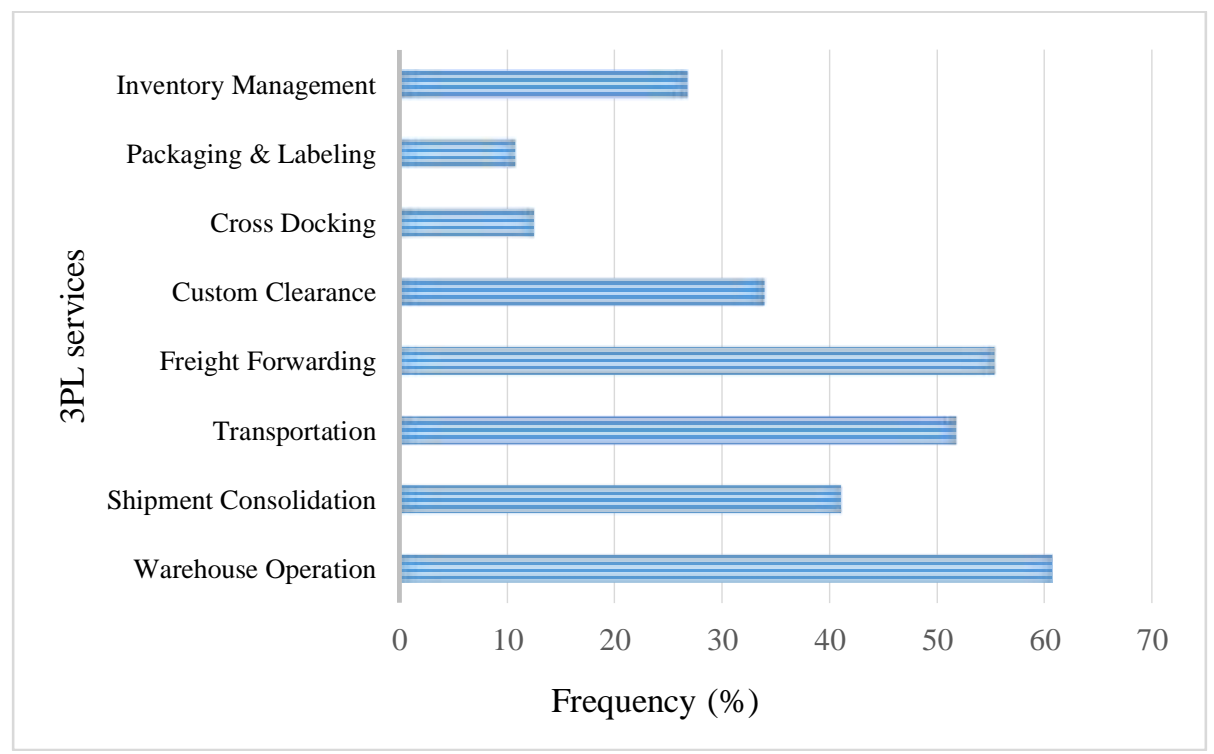

Figure 2:- 3PL services obtained by apparel firms

Source: Developed by the authors (2016)

The average time span of a 3PL agreement is approximately one and half years with maximum of seven years and minimum of 4 months. Table 1 represent the variables and their respective Cronbach alpha values. 


\begin{tabular}{|l|l|}
\hline Variable & Cronbach alpha value \\
\hline CULO & 0.725 \\
\hline SWBE & 0.698 \\
\hline TRUS & 0.712 \\
\hline OPTR & 0.688 \\
\hline EPCO & 0.730 \\
\hline ECOM & 0.732 \\
\hline FLEX & 0.774 \\
\hline FICO & 0.734 \\
\hline COFU & 0.756 \\
\hline CURE & 0.785 \\
\hline
\end{tabular}

Table 1: Reliability statistics

Source: Developed by the authors (2016)

As per Table 1, most Cronbach alpha values exceed 0.7 value except openness and transparency (OPTR), and switching behaviour (SWBE). Since they also have values close to 0.7 , the constructs are considered to be statistically reliable. Test-Retest test was performed to ensure reliability.

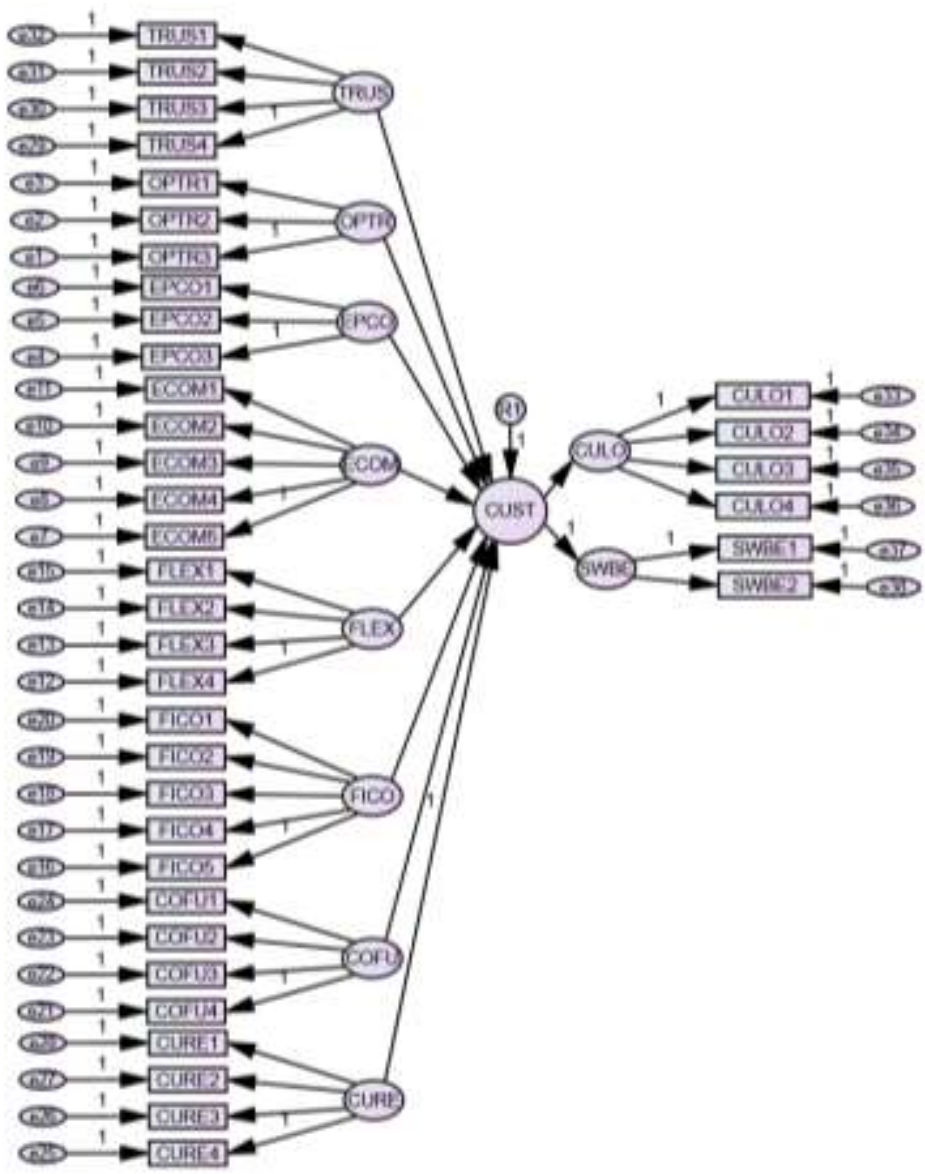

Figure 3:- Conceptual framework in AMOS

Source: Developed by the authors (2016)

Figure 3 represents the conceptual framework of the study derived from AMOS. The variables should generally have communalities greater than the standardized factor loading of 0.5. Since the sample size of this study is comparatively less, factor loadings of 0.40 and higher were considered significant for interpretive purposes. These factor loadings can also be interpreted as the standardized regression coefficients of variables (Rahn, 2016). Further, path values are considered to be significant if the $P$ values are less than 0.1 under 90 percent confidence level. 
Customer satisfaction was viewed on two dimensions in this study, as customer loyalty and switching behaviour. Under customer loyalty, four items were considered while switching behaviour comprised of two items. Figure 4 depicts the covariance value between the two dimensions and the factor loadings of their items. The covariance value should be less than 0.8 and thus, the two dimensions of customer satisfaction are valid.

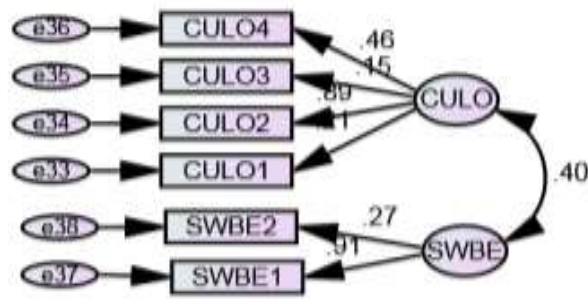

Figure 4:- Covariance of the dimensions of customer satisfaction Source: Developed by the authors (2016)

Figure 4 indicates the factor loadings of items considered under each dimension. As per the figure, CULO1, CULO3, and SWBE2, have values less than the threshold level of 0.4 , and were removed from the respective dimensions. Table 2 represents path values of the items considered under each dimension. When considering $P$ values of the items, except SWBE2, other $p$ values are less than the threshold value of 0.1 . Thus, their path values are significant.

\begin{tabular}{|l|l|l|l|l|}
\hline & & & Estimate & $\boldsymbol{p}$ \\
\hline CULO1 & $<---$ & CULO & 1.000 & \\
\hline CULO2 & $<---$ & CULO & 5.320 & .048 \\
\hline CULO3 & $<---$ & CULO & .856 & .017 \\
\hline CULO4 & $<---$ & CULO & 3.215 & .091 \\
\hline SWBE1 & $<---$ & SWBE & 1.000 & \\
\hline SWBE2 & $<---$ & SWBE & .300 & .456 \\
\hline
\end{tabular}

Table 2:- Path values of the dimensions of customer satisfaction

Source: Developed by the authors (2016)

Figure 5 reveals factor loadings of customer satisfaction dimensions after removing the items related to less factor loadings. Customer loyalty (CULO) and switching behaviour (SWBE) have been merged together and a new construct named customer satisfaction (CUSA) formed. CULO2, CULO4, and SWBE1, are considered as the items of CUSA. When considering the factor loadings of these three items, CULO4 and CULO2 are accepted, since their values are greater than 0.4. Although SWBE1 has a value less than the threshold level of 0.4, it was not removed, since there should be at least one item to represent the dimension of switching behaviour.

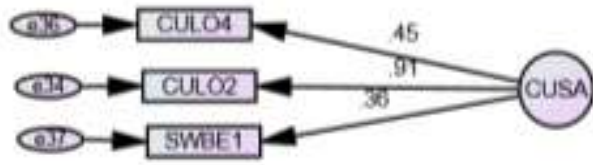

Figure 6:- Factor loadings of modified customer satisfaction dimension

Source: Developed by the authors (2016)

Table 3 presents the $P$ values of CULO2, CULO4, and SWBE1. The path values are significant since $P$ values are less than the threshold level of 0.1 .

\begin{tabular}{|l|l|l|l|l|}
\hline & & & Estimate & P \\
\hline CULO4 & $<---$ & CUSA & 1.000 & \\
\hline CULO2 & $<---$ & CUSA & 1.759 & .089 \\
\hline SWBE1 & $<--$ & CUSA & 0.931 & .037 \\
\hline
\end{tabular}

Table 3:- Path values of modified customer satisfaction dimension

Source: Developed by the authors (2016) 
Figure 6 represents the output of the model after removing the items with low factor loadings from each variable and dimension. Except the items of variables Openness and Transparency, Effective communication, Financial Considerations, Condition Fulfilment, and Customer Relationships, some items of other variables have been removed due to their low factor loadings.

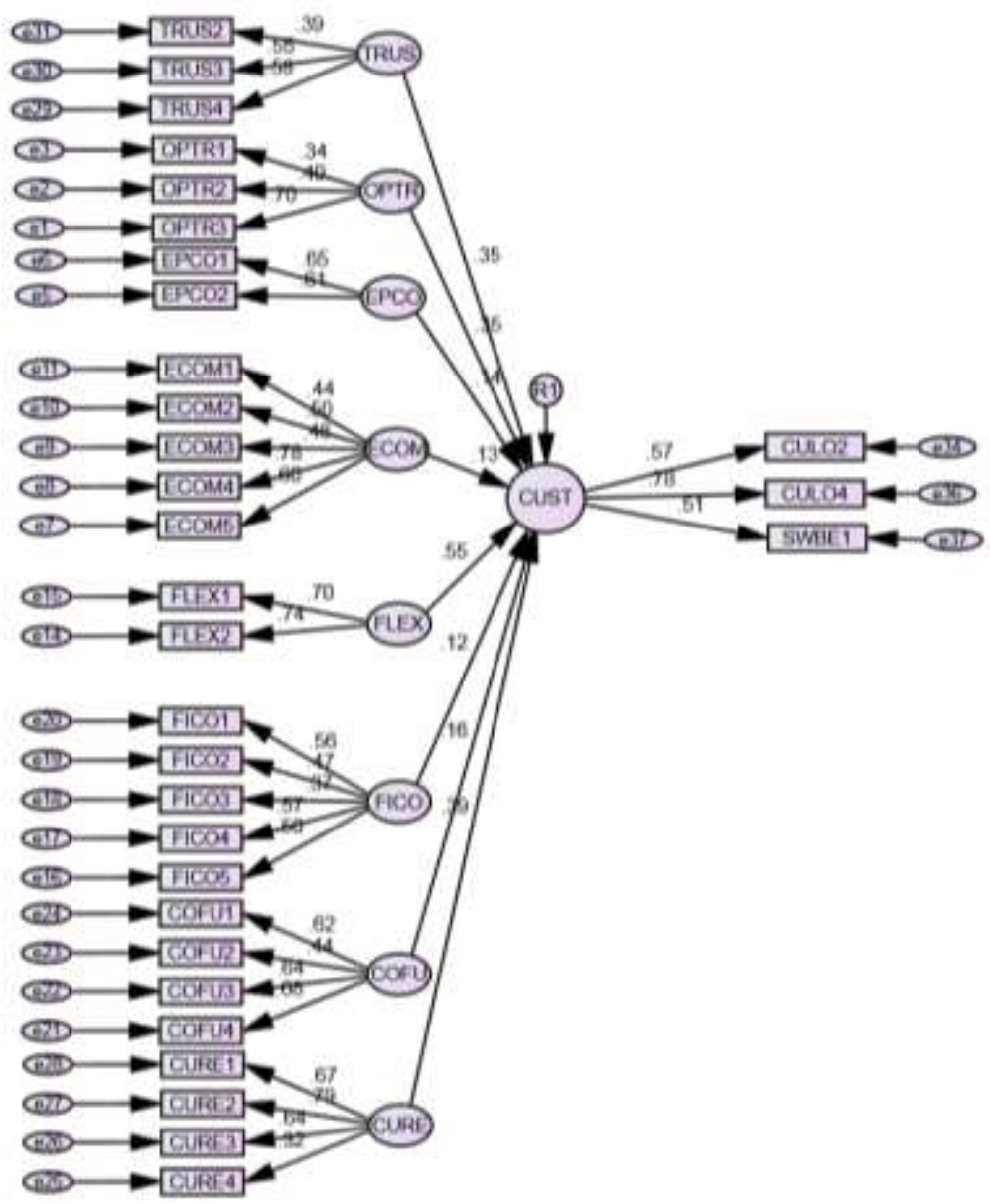

Source: Developed by the authors (2016)

Figure 6:- Output of the structural model

The model fit analyses whether the sample data are consistent with the implied model. The following tables depict the statistics related to the model fit of this study.

\begin{tabular}{|l|l|l|l|l|l|}
\hline Model & NPAR & CMIN & DF & P & CMIN/DF \\
\hline Default model & 67 & 539.079 & 429 & .000 & 1.257 \\
\hline Saturated model & 496 & .000 & 0 & & \\
\hline Independence model & 31 & 756.978 & 465 & .000 & 1.628 \\
\hline
\end{tabular}

Table 4:- CMIN/DF value of the model

Source: Developed by the authors (2016)

The accepted CMIN/DF value of a model should be less than the threshold value of 3. Since the CMIN/DF value is 1.257 , model of the present study has a good fit.

\begin{tabular}{|l|l|l|l|l|}
\hline Model & RMR & GFI & AGFI & PGFI \\
\hline Default model & .042 & .663 & .610 & .573 \\
\hline Saturated model & .000 & 1.000 & & \\
\hline Independence model & .050 & .535 & .504 & .502 \\
\hline
\end{tabular}

Table 5:- GFI value of the model 
Source: Developed by the authors (2016)

Goodness of Fit (GFI) statistic of a model should be scaled between 0 and 1 (Sharma et al., 2005). As the GFI value of 0.663 is in the range, the model is considered as a best fit.

\begin{tabular}{|l|l|l|l|l|}
\hline Model & RMSEA & LO 90 & HI 90 & PCLOSE \\
\hline Default model & .068 & .048 & .086 & .065 \\
\hline Independence model & .107 & .093 & .120 & .000 \\
\hline
\end{tabular}

Table 6:- RMSEA value of the model

Source: Developed by the authors (2016)

The acceptable norm for RMSEA is that the value should be in the range of 0.05 to 0.1 for the model to represent a good fit while values above 0.1 are poor fitting (MacCallum, Browne \& Sugawara, 1996). Generally, the acceptance level of RMSEA value is less than 0.08. As the RMSEA value of 0.068 is in between the above range, less than 0.08 and not closer to 0.1 , the model is well fitting.

\begin{tabular}{|l|l|l|l|l|l|}
\hline Model & $\begin{array}{l}\text { NFI } \\
\text { Delta1 }\end{array}$ & $\begin{array}{l}\text { RFI } \\
\text { rho1 }\end{array}$ & $\begin{array}{l}\text { IFI } \\
\text { Delta2 }\end{array}$ & $\begin{array}{l}\text { TLI } \\
\text { rho2 }\end{array}$ & CFI \\
\hline Default model & .288 & .228 & .664 & .591 & .623 \\
\hline Saturated model & 1.000 & & 1.000 & & 1.000 \\
\hline Independence model & .000 & .000 & .000 & .000 & .000 \\
\hline
\end{tabular}

Table 7:- Baseline comparisons of the model

Source: Developed by the authors (2016)

The acceptable range for both NFI and CFI values are between 0 and 1 whereas values closer to 1 indicate a good fit. However, NFI index is highly sensitive to the sample size (Mulaik et al., 1989; Bentler, 1990) and it is not recommended to be solely rely on this value (Kline, 2005). Contrastingly, CFI is one of the most popularly reported fit as it is one of the measures least affected by the sample size (Fan, Thompson \& Wang, 1999). Since NFI and CFI values of this model are in between the above threshold range, the model indicates a good fit.

According to Figure 6, it was observed that 'Flexibility' and 'Customer Relationship' are the most effective variables to 3PL customers' satisfaction. When Flexibility increases by 1 unit, Customer Satisfaction increases by 0.55 units while keeping all other variables constant. Also, when Customer Relationships increases by 1 unit, Customer Satisfaction increase by 0.39 units while keeping all other factors constant.

\section{Conclusion:-}

The study focused on identifying factors affecting the satisfaction of 3PL customers with special reference to apparel firms in Sri Lanka, to build effective, mutually beneficial, and sustainable long-term relationships between 3PL providers and their customers. 'Trust' has a positive relationship with customer satisfaction with a regression coefficient of 0.35 . Over 90 percent of respondents mentioned that they trust their 3PL providers. 'Openness and Transparency' also has a positive relationship with customer satisfaction with a regression coefficient of 0.35 . Nearly 84 percent agreed that their 3PL providers are open and transparent. 'Customer Relationships' has a positive relationship with customer satisfaction with a regression coefficient of 0.39 . Nearly 88 percent agreed that 'Effective Communication' is vital for 3PL customers' satisfaction. A majority (above 70\%) of the sample indicated that 'Condition Fulfilment', 'Financial Considerations', and 'Effective Partnering and Collaboration' are crucial for 3PL customers' satisfaction.

Out of all the logistics functions considered in the study, warehouse operation is the most common 3PL service obtained by apparel firms. This fact was proved by Hettiarachchi \& Ranwala (2015). Freight forwarding has the second highest frequency and transportation takes the next highest frequency. Further, the average time span of a 3PL agreement is one and half years while average number of 3PL providers used is three, in this study sample. The main research finding of the present study is that 'Flexibility' of the 3PL provider was the most significant factor affecting customer satisfaction while 'Customer Relationships' of the 3PL provider was of second highest significance. In addition, factors such as 'Openness and Transparency' and 'Trust' also had comparatively high significance towards customer satisfaction when compared with rest of the six variables. 
3PL providers should always be flexible with their customers because it is the most significant factor that affects customer satisfaction. Flexibility can be enhanced through building a 'hub and spoke model' where the client is in a centralized location and the 3PL provider set up operations in closer proximity surrounding the centralized location. This will enable 3PL providers to provide service in quick notice and will help them to speed up their services to cater unanticipated situations. Further, it will reduce the time wastage of both parties. In addition, the 3PL provider can set up their branch within the customer's premises, which will help to achieve the target cost reductions.

3PL providers in Sri Lanka always comprises employees hired on contract basis. Their lack of commitment has resulted in poor customer satisfaction. Therefore, recruiting permanent employees will improve customer satisfaction, as they are highly committed and focused. Further, proper chain of command and effective reporting methods should be implemented by 3PL providers because lack of proper communication among the hierarchy levels is one of the common complaints of 3PL customers. Also, before assigning tasks to employees, they should be properly made aware about customer requirements and should be given relevant and adequate training to cater specific customer requirements.

Another way to enhance customer satisfaction is to implement Total Quality Management (TQM) by the 3PL provider among all their services. Implementing such a concept will enable 3PL providers to continuously monitor their service quality and allow them to take quick remedies if any failures are identified, and will build effective customer relationships. In addition, 3PL providers should provide innovative services to their customers as service providers and customers are integrated in the modern business environment. Finally, the 3PL providers should implement an advanced, well-built, and user-friendly Information System (IS), integrating the entire organization. Further, the service provider's IS should comply with those of the customers' and employees should be properly trained on its utilization to obtain the maximum benefit. An effective IS will contribute immensely on improving customer satisfaction.

\section{References:-}

1. Assael, H. (1987) Consumer Behaviour and Marketing Action. Boston, Kent Publishing Company.

2. Autry, C., Zacharia, Z. \& Lamb, C. (2008) A logistics strategy taxonomy. Journal of Business Logistics, 29 (2), 27-51.

3. Bentler, P.M. (1990) Comparative Fit Indexes in Structural Models. Psychological Bulletin, 107(2), 238-246.

4. Bolton, R.N. and Drew, J.H. (1991) A multistage model of customers' assessments of service quality and value. Journal of Consumer Research, 17 (March), 275-284.

5. Bowen, J.T. \& Chen, S.L. (2001) The relationship between customer loyalty and customer satisfaction. International Journal of Contemporary Hospitality Management, 13(5), 213-217.

6. Deerasinghe, R. (2009) Garment Industry in Sri Lanka: Challenges, Prospects and Strategies. Staff Studies, 33(1), 33-72.

7. Etzel, M.A. (1981) The Managerial Perspective on Directions for Retail Customer Dissatisfaction Research. Journal of Retailing, 57(Fall), 124-136.

8. Export Development Board (2016) Sri Lanka Apparel Sector. Industry Capability Report, January, pp. 2-8.

9. Fan, X., Thompson, B. \& Wang, L. (1999) Effects of Sample Size, Estimation Methods, and Model Specification on Structural Equation Modelling Fit Indexes. Structural Equation Modeling, 6(1), 56-83.

10. Fornell, C. (1992) A National Customer Satisfaction Barometer: The Swedish Experience. Journal of Marketing, 56(1), 6-21.

11. Fortin, D., Dholakia, R. \& Dholakia, N. (2002) Emerging issues in electronic marketing: thinking outside the square. Journal of Business Research, 55(8), 623-627.

12. Geyskens, I, Steenkamp, J.B.E.M. \& Kumar, N. (1999) A Meta-Analysis of Satisfaction in Marketing Channel Relationships. Journal of Marketing Research, 36 (May), 223-238.

13. Gro"nroos, C. (1988) Service quality: the six criteria of good perceived service quality. Review of Business, 9(3), 10-13.

14. Guo, L., Xiao, J. J. \& Tang, C. (2009) Understanding the psychological process underlying customer satisfaction and retention in a relational service. Journal of Business Research, 62, 1152-1159.

15. Gwin, J.M. \& Lindgren, Jr. J.H. (1986) Reaching the Service-Sensitive Retail Consumer. Journal of Retail Banking, 8(3), 36-42.

16. Heide, J. B. \& John, G. (1992) Do Norms Matter in Marketing Relationships? Journal of Marketing, 56(2), 3244. 
17. Hettiarachchi, P.B. \& Ranwala, L.U. (2015) Determinants of Customer Satisfaction in Third Party Logistics Outsourcing Relationship in Sri Lanka. In: Goonasekara, C.L., Premaratne, P.H. \& Anandawansa, B.D.K. (eds.) Inculcating Professionalism for National Development: Proceedings of 8th International Research Conference, 27-28 August 2015, Rathmalana, Sri Lanka, pp.126-131.

18. Iacobucci, D., Grayson, K. \& Ostrom. A. (1994) The calculus of service quality and customer satisfaction: Theoretical and empirical differentiation and integration. In: Swartz, T.A., Bowen, D.E. \& Brown, S.W. (eds.) Advances in services Marketing and Management: Research and Practice, 3, Greenwich, JAI Press, pp. 1-67.

19. Jacoby, J. \& Kyner, D.B. (1973) Brand Loyalty versus Repeat Purchasing Behaviour. Journal of Marketing Research, 10 (February), 1-9.

20. Jones, T.O. \& Sasser, E.W. (1995) Why Satisfied Customers Defect. Harvard Business Review, 73(6), 88-99.

21. Juga, J., Juntunen, J. \& Grant, D.B. (2010) Service quality and its relation to satisfaction and loyalty in logistics outsourcing relationships. Managing Service Quality, 20(6), 496-510.

22. Kim, D., Ferrin, D. \& Rao, H. (2009) Trust and Satisfaction, two stepping stones for successful e-commerce relationship: A longitudinal exploration. Information System Research, 20(2), 237-257.

23. Kline, R.B. (2005) Principles and Practice of Structural Equation Modelling ( $2^{\text {nd }}$ ed.). New York, The Guilford Press.

24. Kotler, P. (2011) Reinventing Marketing to Manage the Environmental Imperative. Journal of Marketing, 75(4), 132-135.

25. Kouser, R., Qureshi, S., Hasan, H. \& Shahzad, F. (2012) Factors Influencing the Customer's Satisfaction and Switching Behaviour in Cellular Services of Pakistan. Interdisciplinary Journal of Research in Business, 2(1), 15-25.

26. Kramer, R.M. (1999) Trust and distrust in organizations: Emerging perspectives, enduring questions. Annual Review of Psychology, 50(1), 569-598.

27. Lewis, I. \& Talalayevsky, A. (2000) Third-party logistics: Leveraging information technology. Journal of Business Logistics, 21, 173-185.

28. MacCallum, R.C., Browne, M.W. \& Sugawara, H.M. (1996) Power Analysis and Determination of Sample Size for Covariance Structure Modelling. Psychological Methods, 1(2), 130-149.

29. Mayer, R., Davis, J. \& Schoorman, F. (1995) An Integrative Model of Organizational Trust. Academy of Management Review, 20(3), 709-734.

30. McKnight, D. \& Chervany, N. (2002) What Trust Means in E-Commerce Customer Relationships: An Interdisciplinary Conceptual Typology. International Journal of Electronic Commerce, 6(2), 35-59.

31. Mulaik, S.A., James, L.R., Van Alstine, J., Bennet, N., Lind, S. \& Stilwell, C.D. (1989) Evaluation of Goodness-of-Fit Indices for Structural Equation Models. Psychological Bulletin, 105(3), 430-445.

32. Oliver, R.L. (1999) Whence consumer loyalty. Journal of Marketing, 63 (Special Issue), 33-44.

33. Olsen, S.O. (2002) Comparative evaluation and the relationship between quality, satisfaction, and repurchase loyalty. Journal of the Academy of Marketing Science, 30(3), 240-249.

Parasuraman, A., Zeithaml, V.A. and Berry, L.L. (1985) A conceptual model of service quality and its implications for future research. Journal of Marketing, 49 (4), 41-50.

34. Perera, H. (2011) CILT News. Available from: http://newsletter.ciltsl.com/2011/Q3/ [Accessed 16 ${ }^{\text {th }}$ June 2016$]$.

35. Premarathne, W. (2012) Issues and Trends of Third Party Logistics (3PL) Market in Sri Lanka. In: Patabendi, P. (eds.) Asian Studies Conference Proceedings 2012: Proceedings of the International Conference on Asian Studies, 26-27 July 2012, Negombo, Sri Lanka. pp. 1148-1160.

36. Rahman, S. (2011) An exploratory study of outsourcing 3PL services: an Australian perspective. Benchmarking: An International Journal, 18(3), 342-358.

37. Rahn, M. (2016) Factor Analysis: A Short Introduction, Part 1. Available from: http://www.theanalysisfactor.com/factor-analysis-1-introduction/ [Accessed $15^{\text {th }}$ September 2016].

38. Ranganathan, C., Seo, D. \& Babad, Y. (2006) Switching behaviour of mobile users: do users' relational investments and demographics matter? European Journal of Information Systems, 15(3), 269-276.

39. Sathish, M., Kumar, K.S., Naveen, K.J. \& Jeevantham, V. (2011) A Study on Consumer Switching Behaviour in Cellular Service Provider: a study with reference to Chennai. Far East Journal of Psychology and Business, 2(2), 71-81.

40. Shankar, V., Amy, K.S. \& Rangaswamy, A. (2003) Customer Satisfaction and Loyalty in Online and Offline Environments. International Journal of Research in Marketing, 20, 153-175.

41. Sharma, S., Mukherjee, S., Kumar, A. \& Dillon, W.R. (2005) A simulation study to investigate the use of cut off values for assessing model fit in covariance structure models. Journal of Business Research, 58(1), 935-943. 
42. Sheikh, Z. \& Rana, S. (2012) Role of Third Party Logistics Providers with Advanced IT to Increase Customer Satisfaction in Supply Chain Integration. International Journal of Academic Research in Business and Social Sciences, 2(1), 546-554.

43. Srinivasan, K., Kekre, S. \& Mukhopadhyay, T. (1994) Impact of electronic data interchange technology on JIT shipments. Management Science, 40, 1291-1304.

44. Tian, Y., Lai, F. \& Daniel, F. (2007) An examination of the nature of trust in logistics outsourcing relationshipEmpirical evidence from China. Industrial Management \& Data Systems, 108(3), 347-361.

45. Vaidyanathan, G. (2005) A framework for evaluating third-party logistics. Communications of the ACM, 48(1), 89-94.

46. Wagner, S.M. \& Friedl, G. (2007) Supplier switching decisions. European Journal of Operational Research, 183(2), 700-717.

47. Zeithaml, V., Berry, L. \& Parasuraman, A. (1996) The Behavioural Consequences of Service Quality. Journal of Marketing, 60(2), 31-46. 